\title{
A turizmusbiztonságban rejló marketing és menedzsment implikációk
}

\author{
Szerzők: Marton Zsuzsanna ${ }^{1}$ - Birkner Zoltán² - Keller Krisztina ${ }^{3}$ - Berkesné Rodek Nóra ${ }^{4}$
}

A globális turizmust fenyegetô biztonsági kockázatok negatív hatásai, az iparágra jellemzô multiplikátorhatásból adódóan, a gazdaság egészére továbbgyürüznek. Azonositásuk mind fogyasztói, mind szolgáltatói oldalról szükségszerû́, minimalizálásuk és kiküszöbölésük az értékteremtés feltétele. A turisztikai desztinációkat sújtó katasztrófákra, krízishelyzetekre történô felkészülésben, és az azokat követô válságkezelésben a megfelelö menedzsment- és marketingszemlélet alkalmazása a szektor további "sérülésének" megakadályozását, illetve mielőbbi helyreállitását célozza. A válságkezelési gyakorlat szemléltetése egy angliai száj-és körömfájás járvány, valamint egy ausztrál bozóttúz esetein keresztül történik.

Kulcsszavak: turizmusbiztonság, természeti katasztrófa, kríziskommunikáció, marketingkampány.

\section{Bevezetés és irodalmi áttekintés}

Az évezredes múltra visszatekintő iparág, a turizmus, az idők folyamán egy olyan globális jelenséggé nőtte ki magát, mely a világpiaci export $7 \%$-át, a GDP 10\%-át tette ki 2016-ban. A gazdasági mutatók az előrejelzések szerint a következő években még kedvezőbb képet mutatnak majd (UNWTO 2017, WTTC 2017, UNWTO 2018).

Számos régió gazdaságában a turizmusipar jelenti az egyetlen fó bevételi forrást, így egyértelmúen kijelenthető, hogy a turisták biztonságának és védelmének garantálása stratégiai fontosságú célként kell, hogy megjelenjen a turisztikai desztinációk stratégiájában, és a szolgáltatók üzletpolitikájában.

\subsection{A BIZTONSÁG SZEREPE A TURIZMUSBAN}

Az elmúlt bő másfél évtizedben megszaporodott terrortámadások következtében a biztonság turizmusiparban betöltött szerepe a korábbiaknál nagyobb hangsúlyt kap mind keresleti, mind kínálati oldalon. A biztonság a turizmusban nem csupán az egész iparág múködését befolyásolhatja alapve-

\footnotetext{
1 PhD-hallgató, Pannon Egyetem Nagykanizsai Kampusz, mzsuzs89@gmail.com

2 egyetemi docens, Pannon Egyetem Nagykanizsai Kampusz, birkner.zoltan@uni-pen.hu

3 egyetemi docens, Pannon Egyetem Nagykanizsai Kampusz, keller.krisztina@gmail.com

4 egyetemi oktató, Pannon Egyetem Nagykanizsai Kampusz, rodek.nora@uni-pen.hu
}

tően, hanem a közvetlen környezetünkben található turisztikai terekben és miliőben is meghatározó pozitív szereppel bír (ZSARNOCZKY 2017, DÁVID - MOLNÁR 2007). Ennek következtében a turisztikai iparág szolgáltatói mérhetően szembesülnek egy-egy váratlan esemény rövid- vagy akár hosszútávú hatásaival (például visszaesés a turistaforgalomban és bevételekben, a ráfordítások növekedése). A negatív események a turisták fogyasztói szokásaiban és magatartásában jelentős változásokat idézhetnek elő (MICHALKO 2012), mely a bizalom megrendülését vonja maga után a turisztikai desztinációkkal, szolgáltatókkal szemben. Az UNWTO 2015-re vonatkozó jelentésében a biztonság az elsô három, turistaforgalmat befolyásoló tényező között szerepelt (UNWTO 2016).

MANSFELD és PIZAM (2006:139-141) az utazások során felmerülő kockázatoknak, fenyegetettségeknek az alábbi öt csoportját különbözteti meg:

- Búncselekménynek a turisták közbiztonságát szándékosan fenyegetô, illetve sértô eseményeket tekintik: köztereken, busz- és vasúti pályaudvarokon zsebtolvajlás, erőszakos búncselekmények, robbantások, szexuális zaklatás, kábítószercsempészet.

- Az egészségbiztonságot fenyegetô kockázatok között a vírus- és baktériumfertőzéseket említi a szerzoopáros, melynek negatív hatásait a küldő régió is elszenvedheti (ritka fertőzések behozatala).

- A helyi közlekedésból, illetve annak hiányos ismeretéből fakadó közúti balesetek, a légi és vasúti katasztrófák megjósolhatatlan biztonsági kockázatot hordozó történések.

- A negyedik csoportba tartoznak a természeti katasztrófák (például földrengések, heves szélviharok, áradások). 
- A különböző politikai-kulturális helyzetek és fenyegetettségek (a helyi törvények és vallási szokások nem megfelelő ismerete) kerültek az utolsó kategóriába.

A tanulmány a fenti csoportosítást veszi alapul, mely a turistákra, mint „áldozatokra” tekint és az óket fenyegetó kockázatokat ebból a nézópontból tárgyalja. Azonban találkozhatunk olyan esetekkel is, amikor a turista nem áldozat, hanem elkövetó (például lopás, vandalizmus) (ERNSZT 2016).

A turizmusipar sokszínúségéból és szerteágazottságából adódóan nem lehet egyetlen kategorizálást alkalmazni a turizmus altípusaira. A turisztikai desztináció jellege (például üdüló vagy MICE fogadóterület, vízparti vagy hegyvidéki fogadóterület) nagyban meghatározza a biztonsági és kockázati tényezők számának és mértékének azonosíthatóságát. Az egyes turizmusfajtáknak természetesen vannak elválaszthatatlan tulajdonságai, mint például a sportturizmusban bekövetkezó sérülések nagyobb kockázata, vagy a városi fogadóterületeken az életkörülményekből fakadó közbiztonsági kockázatok.

\subsection{A MARKETING SZEREPE A TURIZMUSBAN}

A turisztikai termékek és szolgáltatások egyre gyakoribb igénybevételével életünk szerves részévé vált az utazás. Az évről-évre növekvő turistaforgalom a turisztikai célterületek és szolgáltatók között még jobban kiélezi a versenyhelyzetet. Ebben a kihívásokkal teli piaci környezetben a döntéshozók felismerték, hogy a versenyképesség eléréséhez és megtartásához nélkülözhetetlen a marketing és annak megfelelő alkalmazása, hiszen a versenyképesség eléréséhez elengedhetetlen elvárás a marketingkörnyezethez történő alkalmazkodás (GÁTI - KOLOS 2012). A turisták egyedi igényeihez való alkalmazkodás képessége vagy a differenciálódás megteremtése a versenykörnyezetben olyan kihívások, melyek jól felépített marketingstratégiát kívánnak meg.

A turizmusmarketing fó területei

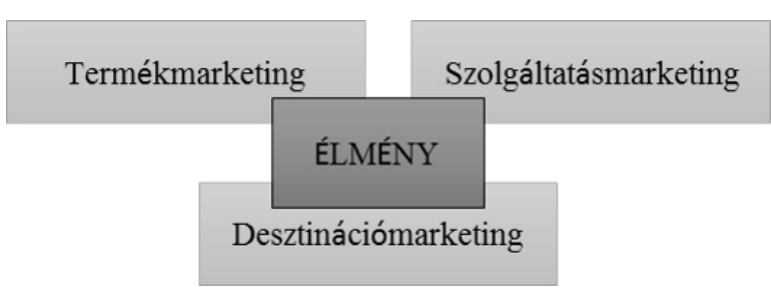

Forrás: RAFFAY (2017:21)
A turizmus nem csak a szervezeti-rendszertani felépítését tekintve összetett, a marketing szempontjából is komplex területról beszélünk. Három egymással szoros összefüggésben álló részterületet különíthetünk el, melyek legfontosabb közös jellemzője az élmény (1. ábra).

A tanulmány célkitúzése szempontjából meg kell említeni, hogy a szolgáltatás- és desztinációmarketing területe az, amely tágabb dimenzióban összevethetô a turizmusbiztonság témakörével.

A turizmusban a szolgáltatásmarketing a turisztikai termékekhez (attrakciókhoz) közvetlenül vagy közvetetten kapcsolódó szolgáltatásokkal foglalkozik.

Egy jól átgondolt és megtervezett szolgáltatási folyamat csökkenti az igénybevétel során felmerüló hibakockázatot. Annak ellenére, hogy elôzetes kipróbálásra nincs lehetóségük, a szolgáltatás folyamatának ismerete magasabb fokú biztonságérzetet nyújt a turisták számára. Az utazók véleményét a fizikai környezet (például épületek állapota, a belsô enteriôr, a személyzet megjelenése) nagymértékben befolyásolja, így annak kialakítása a menedzserek egyik kiemelt feladatává vált. A legnehezebben befolyásolható és ellenőrizhető ",elem” a szolgáltatási folyamatban részt vevő személyzet. A fogyasztók és a személyzet közötti interakciók egyaránt eredményezhetik a márkahúség kialakulását, de a szolgáltatástól való teljes elfordulást is.

Mivel a desztinációk a turisztikai termékek és szolgáltatások egymástól elválaszthatatlan ötvözetei, így a marketingstratégiai döntéseknél meghatározó a szerepük. A turisztikai fogadóterületek marketingpolitikája azonban sokkal tágabb menedzsmentszemléletet igénylő tevékenység. A desztinációmarketing célja, hogy a piaci kereslet és a versenytársak ismeretében minél több turistát vonzzon a fogadóterületre, és fenntartsa annak népszerúségét (KOTLER et al. 2010, PÉTER NÉMETH 2017). A desztinációmarketing - a termék- és szolgáltatásmarketinggel ellentétben - sokkal nagyobb hangsúlyt fektet a turizmusiparnak az állami szervezetekkel való együttmúködésére.

\subsection{A TURIZMUSBIZTONSÁG ÉS A MARKETING ÖSSZEFÜGGÉSEI}

A biztonság a turisztikai szolgáltatásminőség kialakításában meghatározó szerepet játszik, ugyanis befolyásolhatja, sőt meg is határozhatja a turisták utazási döntéseit, szokásait. Az elmúlt évek terrorcselekményeinek hatására a turizmusbiztonság a differenciálás eszközévé válhat az iparágban. A turizmus egyes típusait (például síturizmus) jellemzô szezonalitásból fakadó keresletingadozások mellett egy-egy biztonságot csökkentó fenye- 
getettség is extrém eltéréseket idéz elő a foglaltsági mutatókban.

A kockázat fogalmának turizmus területén történő használata a 2001. szeptember 11-i terrortámadásokat követően vált tudományos értekezések kutatási tárgyává. A terrortámadás előtt a kockázatok értelmezése elsősorban pénzügyi, pszichológiai, elégedettségi és idő fókuszú volt, azt követően viszont felértékelődött a fizikai kockázat (YANG - NAIR 2014, DÁVID et al. 2007). A SARS-vírus 2003-as megjelenése, a 2004-es cunami pusztító rombolása Dél- és Dél-Kelet Ázsiában, valamint a szélsőséges iszlamista terrorszervezetek Európára mért támadásai csak néhány példát jelentenek, melyek a turizmusbiztonság és a kockázatok komolyabb vizsgálatát indokolják.

Utazási célterületeik kiválasztása előtt a turisták törekszenek a kockázatok mérséklésére. A korábbi negatív tapasztalat vagy a kellő információ hiánya bizonytalanságot szül a fogyasztókban, mely esetleg egy veszteséggel járó rossz döntést idézhet elő (BAUER et al. 2007).

A legtöbb kutató az észlelt kockázat értelmezésével és annak továbbfejlesztésével foglalkozik. A turizmusban kockázat alatt a fogyasztók turisztikai termékek és szolgáltatások igénybevétele közben tapasztalt és észlelt kockázatát értjük (REISINGER - MAVONDO 2005). ROEHL és FESENMAIER (1992) az észlelt kockázat három dimenzióját különböztetik meg: fizikai eszközökhöz kapcsolódó kockázat (légi utazás), vakáció specifikus kockázat (vízparti turizmus) és desztináció specifikus kockázat (közel-keleti veszélyes övezetek). A biztonság mindhárom dimenzióban központi helyen áll. A desztináció specifikus kockázatok, beleértve az idegen kultúrák, szokások ismeretlenségének kockázatát, a fogyasztókban a kulturális sokk mértékének növekedését idézhetik elő (MALOTA - MITEV 2013). Az észlelt biztonsági kockázatok nagyban befolyásolják az utazási hajlandóságot és döntést. Vannak esetek, amikor olyan magas az észlelt kockázat szintje, ami a nemzetközi turizmus teljes ellehetetlenüléséhez vezet (1. táblázat) (KARL - SCHMUDE 2017).

Jelen tanulmány a kockázatot negatív tényezőként értelmezi és jeleníti meg, említést kell tenni azonban azokról a turistákról is, akik a kockázatra motivációs tényezóként tekintenek. A fogyasztói személyiségjegyek, a társadalmi, kulturális trendek a fogyasztók egy részét arra sarkallják, hogy a veszélyt, a szenzációt keressék (LEPP - GIBSON 2007). A veszély, a fizikai és szociális kockázat az, ami ezen fogyasztók számára az élményt jelenti és egyidejúleg az értéket teremti. A szenzáció, újdonságkeresés sajnálatos módon egyre gyakrabban alakul át katasztrófaturizmussá, mely különböző etikai kérdéseket vet fel.

\section{Nemzetközi utazásokat befolyásoló kockázati tényezók}

\begin{tabular}{|c|c|}
\hline $\begin{array}{l}\text { Kockázati } \\
\text { tényezố }\end{array}$ & Fogalom \\
\hline Funkcionális & $\begin{array}{l}\text { Nemzetközi utazások során felmerüló } \\
\text { szervezeti vagy mechanikai problémák } \\
\text { lehetôsége }\end{array}$ \\
\hline $\begin{array}{l}\text { Fizikai/ } \\
\text { egészségügyi }\end{array}$ & $\begin{array}{l}\text { Utazás során felmerülő fizikai veszély, } \\
\text { sérülés, betegség lehetôsége }\end{array}$ \\
\hline Pénzügyi & $\begin{array}{l}\text { Ár-érték arány nem megfelelő } \\
\text { szintjének lehetôsége }\end{array}$ \\
\hline Társadalmi & $\begin{array}{l}\text { A társadalmi jólét szintjének } \\
\text { visszatükrözódése mások számára }\end{array}$ \\
\hline Pszichológiai & $\begin{array}{l}\text { Az utazás általi önmegvalósitás } \\
\text { elmaradásának kockázata }\end{array}$ \\
\hline Idô & Az utazás az idô vesztegetése \\
\hline Elégedettség & $\begin{array}{l}\text { Elvárt elégedettségi szint } \\
\text { elmaradásának kockázata }\end{array}$ \\
\hline $\begin{array}{l}\text { Politikai } \\
\text { instabilitás }\end{array}$ & $\begin{array}{l}\text { Utazások során felmerülő politikai } \\
\text { instabilitás, feszülltség lehetséges } \\
\text { hatásai a turistákra }\end{array}$ \\
\hline Terrorizmus & $\begin{array}{l}\text { Terrorista cselekmények lehetséges } \\
\text { közvetlen, közvetett hatása a turistákra }\end{array}$ \\
\hline Klima & $\begin{array}{l}\text { Szélsôséges időjárás bekövetkezésének } \\
\text { vagy desztinációra jellemzố elvárt } \\
\text { idôjárás elmaradásának lehetôsége }\end{array}$ \\
\hline
\end{tabular}

Forrás: saját szerkesztés KARL és SCHMUDE (2017:143) nyomán

\section{Válságkezelés és kríziskommunikáció}

A turisztikai desztinációkat legtöbbször váratlanul sújtó természeti katasztrófák, támadások olyan mértékú veszteséget (profitabilitás és/vagy piaci részesedés csökkenése) okozhatnak az adott fogadóterületnek és közvetetten az egész iparágnak, hogy a krízisek stratégiai szinten történő kezelése már-már alapkövetelmény a szervezetek részéről. A megelőzés és a felkészülés egyre hangsúlyosabb szerepet kapnak a stratégiai tervezés során, azonban még mindig gyakori, hogy a megfelelő menedzsment- és marketingszemlélet hiánya miatt hosszútávú negatív hatásokkal kell szembesülni.

A tanulmány eddigi fejezetei a turizmusbiztonság témakörét érintő marketing elméleteket, illet- 
ve a fogyasztók és a biztonság kapcsolatát tárták fel. Azonban a krízismenedzsment és kríziskommunikáció tudományterületén keresztül adunk választ arra, hogy milyen módon csökkenthetó az észlelt kockázat a fogyasztók szemszögéból, s milyen stratégiai lépések szükségesek a támadást elszenvedő vagy katasztrófa sújtotta desztinációk vezetôi részéről.

A tanulmány során többször említett katasztrófa és krízis kifejezéseket a szakirodalom elkülöníti. FAULKNER (2001) szerint a két fogalom eredetében és kiterjedése mértékében különbözik. Míg a krízis eredetét tekintve szervezeten belül jön létre és részben kontrollálható, addig egy katasztrófa külső csapás, támadás kontrollálhatatlan hatásának eredménye, ami terjedelmében is jóval kiterjedtebb és súlyosabb, mint a krízis. A két fogalom azonban számos közös vonást mutat, és nehezen választható szét egymástól, hisz egy katasztrófa gyakran szervezeten belüli krízist idéz elő (HENDERSON 2003).

A kríziskommunikáció egyik modellje három lépcsóben javasolja a helyzetet kezelni (FALL MASSEY 2005). A modell FAULKNER (2001) alapmodelljének egyszerúsített változata (2. ábra). dia, negatív szájreklám) keresztül történő információáramlást.

Az utolsó fázisban, a helyreállítás szakaszában folyamatos kommunikációs tevékenységével a marketing és kríziskommunikációs csapat a bizalom újbóli kiépítésére összpontosít, mely elôsegíti a korábbi múködéshez való visszatérést. A csapat által irányított kétoldali kommunikációban a média tevékenysége korlátozottabbá és tudatosabbá válik. A kommunikációs csapat feladata a hiteles és pontos tájékoztatás minden érintett felé, egységes üzenetközvetítéssel. A krízis okainak, várható következményeinek jellemzése és az ezzel kapcsolatos információk eljuttatása, továbbá a folyamatos elérhetôség csökkentik a pánikot és az észlelt kockázat szintjét. Az egységes kommunikáció megvalósításában az integrált marketingkommunikáció koncepciója szolgálhat alapul. Ennek lényege, hogy öszszehangolja a szervezettól, vállalattól származó információkat, melyet ugyan a fogyasztók (turisták, helyi lakosok) felé többféle kommunikációs csatornán és eszközön juttat el, viszont a megjelenítés ugyanazon az arculaton keresztül történik (TÓTH-KASZÁS 2017).

\section{Kríziskommunikációs folyamat}

\begin{tabular}{|c|c|c|}
\hline $\begin{array}{l}\text { Előkészület } \\
\text { Kríziskommunikációs } \\
\text { terv készítése } \\
\text { Kommunikációs felület } \\
\text { megteremtése } \\
\text { Kríziskommunikációs } \\
\text { csapat felállitása }\end{array}$ & $\begin{array}{l}\text { Válaszadás } \\
\text { Kríziskommunikációs } \\
\text { terv alkalmazása } \\
\text { Együttmüködés, } \\
\text { kommunikáció az } \\
\text { érintettekkel (imázs } \\
\text { fenntartása) }\end{array}$ & $\begin{array}{c}\text { Helyreállitás } \\
\text { Kommunikációs, } \\
\text { válaszadási tevékenység } \\
\text { folytatása } \\
\text { Bizalom megteremtése, } \\
\text { visszatérés a normál } \\
\text { müködéshez }\end{array}$ \\
\hline
\end{tabular}

Az előkészület fázisában az elsődleges cél egy olyan együttmúködési közeg megteremtése az érintett külső és belsô szervezetekkel, iparági szereplőkkel, mely nélkülözhetetlen az elismertség fenntartásához és a krízis átvészeléséhez. Ezzel egyidejúleg készül el a kríziskommunikációs terv, és kerül kinevezésre a felelős csapat.

A második fázis a válaszadásra fókuszál. Ezen belül először tájékoztatják a szektor kulcsszereplőit, döntéshozóit, majd a PR ügynökségekből, jogi képviselőkből, vállalati képviselőkből öszszeálló kommunikációs csapat egyeztetései, akciói következnek. Ebben a fázisban a gyorsaság alapvetô követelmény, meg kell előzni a nehezen kontrollálható kommunikációs csatornákon (mé- 
FAULKNER (2001), illetve FALL és MASSEY (2005) a turisztikai desztinációk válságkezelésénél a többlépcsős kríziskommunikációs modellek alkalmazásában látják a megoldást. A tanulmány szerzői ezen folyamatmodell mentén történő válságkezelés szükségességét és hatásosságát vizsgálják, továbbá elemzik a marketing- és menedzsmentszemlélet gyakorlati implementálásának sikerességét a kríziskezelésben.

A kutatáshoz a szerzők az esettanulmány-elemzés módszerét választották, mellyel két külföldi katasztrófa elemzése kerül a középpontba. Az esettanulmány-elemzés módszere olyan kutatásoknál is segít értelmezni az adatokat, információkat, ahol nagy vizsgálati mintaszám elérése nem kivitelezhető, ugyanakkor az események sorrendje, a viselkedési reakciók és a háttérinformációk kiemelt fontosságúak. Ezen kívül az elemzési módszer lehetóséget biztosít további kutatási kérdések megalapozására és hipotézisek felállítására (EISENHARDT 1989).

\subsection{A SZÁJ- ÉS KÖRÖMFÁJÁS JÁRVÁNY}

Az esettanulmány bemutatásának elsődleges célja, hogy rávilágítson a tervszerú válságkezelés fontosságára, illetve az annak hiányában jelentkező buktatókra és a további következményekre.

2001 februárjában 1967. óta elôször, újra felütötte fejét a száj- és körömfájás vírus az Egyesült Királyságban (3. ábra). Összesen 2030 esetet regisztráltak (a vírus több mint 4 millió állat elégetését követelte meg), a járvány terjedéséról a média világszerte hírt adott. A járványhelyzet az angol turizmusban 8,5 milliárd angol font bevételkiesést okozott 2001 és 2003 között. 2002 januárjában, 11 hónappal a járvány kitörését követôen, a kormány hivatalosan is bejelentette a járvány megszúnését. Ennek ellenére a betegség a mezógazdaság mellett a turizmusipart is mélyen érintette, megkérdójelezve a kormány és a turisztikai szektor felkészültségét és szakmai hitelességét a válságkezelés során (RITCHIE et al. 2004).

Mint a legtöbb ilyen esemény, ez is váratlanul érte a turizmust, de ez nem lehet kifogás arra, hogy az iparági szereplők válságmenedzsment stratégia és terv hiányában nem megfelelő módon és időben reagáltak az eseményekre sem helyi, sem nemzeti szinten. A média erejét és hatását lebecsülve gyorsan negatív publicitást kapott az angol turizmus.

A különböző szintek döntéshozói közötti kommunikáció és egységes fellépés hiánya, a megválaszolatlanul hagyott kérdések további bizonytalanságot idéztek eló a turisztikai szolgáltatók körében az attrakciók és a látogatókat kiszolgáló helyi egységek üzemelését és bezárását illetôen.
Mind a turisztikai, mind a kormányzati szervek eltéró és hiányos adatokat közöltek a betegségről, az érintett területekről és az esetek számáról, így a turistáknak az otthon maradás jelentette a biztonságot.

\section{3. ábra}

A száj- és körömfájás vírus terjedési útvonala az Egyesült Királyságban

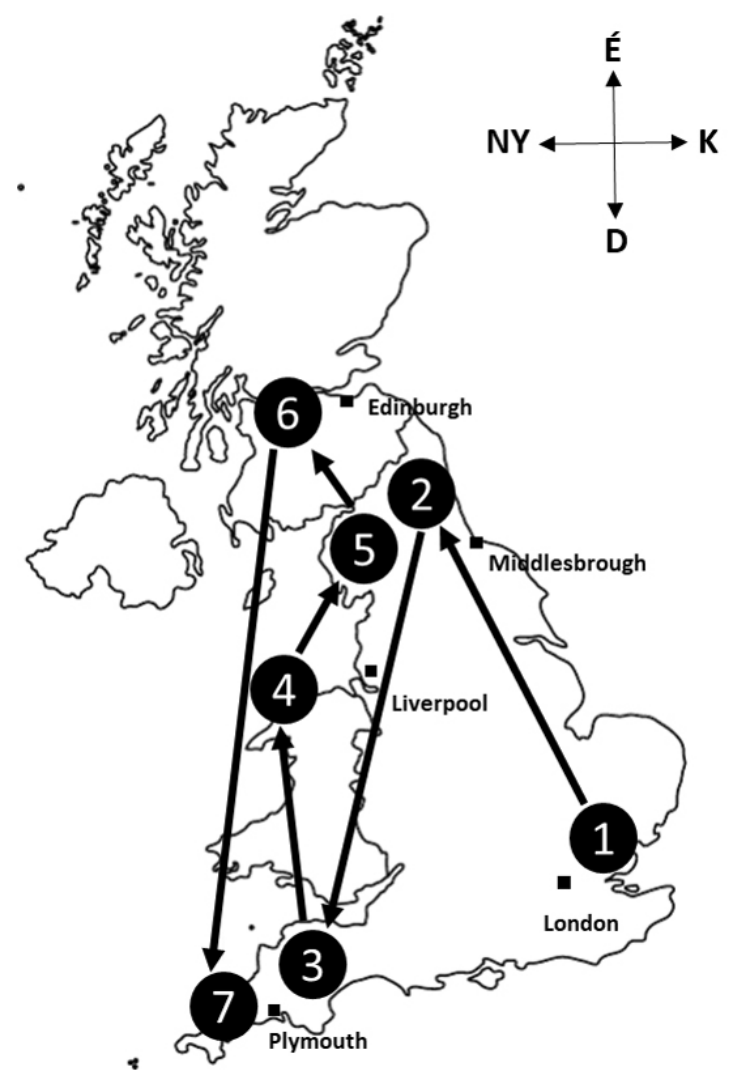

Forrás: saját szerkesztés BBC (2002) nyomán

Egyértelmúen kimondható, hogy az Egyesült Királyság területére beutazott turisták számára egészségügyi kockázatot jelentett a vírus, azonban a pontatlan tájékoztatás pszichológiai és pénzügyi kockázatot is maga után vont, ugyanis a turisztikai látványosságok, vonzerők bezárásával a turistákat egyrészt anyagi károk érték, másrészt az élményszerzés elmaradásával az értékteremtés is meghiúsult.

Az ország márkaértékét csökkentette a fertőzött állatok égetése (vakcina beadása helyett) miatt kialakult negatív imázs és a társadalmi felelősségvállalás szemléletének hiánya (állatvédelem-etikai kérdések). Az eset kezelése jól tükrözi, hogy a válságkezelés kezdetén a turizmus nem kapott központi szerepet (RITCHIE et al. 2004). 
Válságmenedzsment terv hiányában már csak egy utólagos „helyreállító” marketingstratégia alkalmazása javíthatott a helyzeten.

$\mathrm{Az}$ Angol Turizmus Tanács (English Tourism Council) és a Brit Turisztikai Szövetség (British Tourist Authority) 2001 áprilisa és 2002 áprilisa között több millió fontot költött a brit turizmust újjáépító kampányokra és egyéb marketingakciókra, melyeket a 2. táblázatban tekintünk át.

2. táblázat

\section{A Brit Turisztikai Szövetség válságkezeló} marketingstratégiája

\begin{tabular}{|c|c|}
\hline $\bar{ن}$ & $\begin{array}{l}\text { megtévesztổ információk korrigálása és a } \\
\text { turisztikai küldőterületek tájékoztatása }\end{array}$ \\
\hline \multirow{3}{*}{$\frac{\frac{u}{0}}{\frac{0}{\pi}}$} & $\begin{array}{l}\text { - nemzetközi PR ügynökség megbízása az észlelt } \\
\text { kockázat csökkentésére }\end{array}$ \\
\hline & $\begin{array}{l}\text { - informatív weboldal létrehozása a turisztikai } \\
\text { attrakciók elérhetôségéröl, üzemeléséröl }\end{array}$ \\
\hline & $\begin{array}{l}\text { - média bulletin és hírlevelek a hiteles } \\
\text { információ terjesztéséért }\end{array}$ \\
\hline نี & $\begin{array}{l}\text { nyári foglalások biztositása és egységes } \\
\text { kommunikáció megteremtése }\end{array}$ \\
\hline \multirow{3}{*}{ 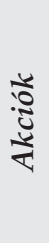 } & - marketingkutatás és reklám, hirdetések \\
\hline & $\begin{array}{l}\text { - nemzetközi e-mail kampány } 10 \text { millió fö } \\
\text { megcélzásával }\end{array}$ \\
\hline & - sajtóutak szervezése \\
\hline ষ্য & az Egyesült Királyság imázsának újjáépítése \\
\hline$\frac{\dot{\gamma}}{\frac{\pi}{\pi}}$ & $\begin{array}{l}\text { - UK OK és „Only in Britain: Only in 2002" } \\
\text { kampány bevezetése }\end{array}$ \\
\hline
\end{tabular}

Forrás: saját szerkesztés RITCHIE és szerzőtársai (2004) nyomán

A stratégia nemzeti szinten történő alkalmazását gátolta, hogy a vírus terjedése nem minden területet érintett. Ennek ellenére nem volt olyan régió, mely ne érezte volna a járvány turizmusra gyakorolt hatását. A válságkezelés és az újjáépítố marketing a vírus teljes megszúnéséig szinte teljesen hatástalannak bizonyult.

\subsection{AZ AUSZTRÁL BOZÓTTÜZ - „THE HEART" MARKETINGKAMPÁNY}

A tanulmány ezen fejezete az ARMSTRONG és RITCHIE szerzőpáros 2008-ban publikált kutatásában közzétett információkat ismerteti.
2003. január 8-án az Australian Capital Territory (Ausztrál Fôvárosi Terület) több pontján bozóttüzek keletkeztek egy elektromos vihar következtében, melynek terjedését felgyorsították a kedvezőtlen idôjárási feltételek. Az esetet a január 18-i canberrai túzvésszel azonosítják annak ellenére, hogy addigra már kritikus mértékú károkat okozott az erdőkben, vidéki területeken.

A bozóttúz az Australian Capital Territory nyugati részén fekvő nemzeti parkokban, ültetvényeken, természetvédelmi területeken és kulturális örökségekben végzett súlyos pusztítást, azonban nem csak az ökológiai, kulturális veszteség volt nagy, hanem a területen kiépült infrastrukturális hálózat (kempingek, parkolók, szabadidős eszközök) károsodása is.

Kríziskommunikáció és „helyreállító” marketingterv hiányában az Australian Capital Tourism Corporation (Ausztrál Fóvárosi Turizmus Társaság) a Blue Mountains és Illawarra-South Coast marketingterve alapján kezdett hozzá a stratégia kidolgozásához, illetve azzal párhuzamosan végrehajtásához.

Első lépésben a Tourism Industry Council ACT (Ausztrál Fővárosi Terület Turisztikai Tanácsa) és a Region Ltd. egy kérdôíves felmérés elvégzésével, valamint a turisztikai szektor érintettjeivel folytatott mélyinterjúk segítségével feltérképezte a túzvész turizmusra gyakorolt hatását és annak mértékét. A desztinációt nem csak a természeti katasztrófa sújtotta, hanem a média szenzációhajhász fellépése is, melyek együttes hatása a látogatók számának drasztikus csökkenésében, illetve a helyi vállalkozások összeomlásában mutatkozott meg.

A kutatás eredményeit felhasználva az Australian Capital Tourism Corporation elindította a „The Heart” marketingkampányt, melynek célja, hogy felhívja a lakosok és látogatók figyelmét a desztinációra mint fó turisztikai fogadóterületre.

A kampány 2003. február 2-án kezdődött a nyomtatott sajtóban, majd márciusban folytatódott a televíziós kampánnyal. „A szívünk még mindig erősen dobog" üzenettel kívánták az érintett és a többi ausztrál állam lakosságában tudatosítani, hogy a bozóttúz ellenére Canberra és az Australian Capital Territory visszatért a régi kerékvágásba. A televíziós kampány márciusban kezdődött, melyben az ausztrál énekes Jimmy Barnes 'This heart's still going strong' címú számát játszották. A kampány hatásosságát 2003 májusában egy újbóli telefonos felméréssel vizsgálták, mely már pozitív képet mutatott az utazási hajlandóságot és a desztináció imázsát tekintve.

A helyreállító kampány a kezdeti stratégiai hiányosságok ellenére a válságkezelés kulcsa volt, 
azonban számos lépés segítette hozzá a turisztikai desztinációt ahhoz, hogy visszatérjen a válság előtti állapotba. A katasztrófa idejére kihirdetett rendkívüli állapot megszüntetését (2003. január 28.) követően azonnal megkezdték a kampány szervezését és pár napon belüli kivitelezését. Ugyan több mint két hét telt el a bozóttûz kitörése és az első nyomtatott kampányanyag publikálása között, mégis adott körülmények között időben reagáltak a történésekre. A nyomtatott kampányanyag gyors elkészítését elősegítette, hogy a kampányüzenetet csak integrálni kellett a már korábban elkészített őszi brosúrába. A marketingkampány során az érintettekkel való szoros kommunikáció elhagyása vitatható lépés, azonban a gyors reakció és a kampány kivitelezése érdekében ez volt az egyetlen járható út. Az egységes üzenetközvetítést megfelelően támogatták a médiamegjelenések a helyi lakosok és a kontinensről érkezó látogatók felé, továbbá mérsékelték az észlelt kockázat mértékét. A kampány ereje egyrészt az őszinte és nyílt kommunikációban, másrészt abban rejlett, hogy a kampány élén álló szóvivók szintén a katasztrófa sújtotta területen éltek, így hatásosabb és hitelesebb tájékoztatást nyújtottak.

\section{Következtetések}

A krízist elszenvedett turisztikai desztinációk válságmenedzsment és kommunikációs stratégiájának, akcióinak hatékonysága, avagy hosszútávú kedvezô hatása nehezen mérhetô. Mindkét eset ismertetése és elemzése során központi szerepet kapott a kommunikáció és a marketingkampány, ugyanakkor a két eset jól példázza, hogy menedzsment szempontból a szervezeten belüli és kívüli együttmúködések, kapcsolati háló és az iparági, illetve kormányzati szereplők feladatainak stratégia meghatározása más-más irányba mozdíthatja a válságkezelést.

Az ausztrál eset azt mutatja, hogy egy meglévő cselekvési terv adaptálását követően már hatékonyabb válságkezelést lehet véghezvinni, az angolokkal ellentétben. Az ausztrálok a kampány indítása előtt felmérést végeztek, mely szintén tudatos válságkezelési lépésnek bizonyult, de sem az angolok, sem az ausztrálok nem követtek egyetlen kríziskommunikációs modellt sem. FAULKNER (2001), illetve FALL és MASSEY (2005) az előkészületi fázist a folyamat lényeges és szükségszerú lépcsőjének tartják, azonban egy hiteles és több érintettet (például helyi lakosokat, turistákat, turisztikai vállalkozásokat) megcélzó kampány s képes a válság előtti helyzet visszaállítására.

A kríziskommunikációs terv nélkülözhetetlenségét a 2011-es norvég terrortámadás esete is cá- folja. 2011. július 22-én egy szélsőjobboldali nacionalista férfi autóba rejtett pokolgépet robbantott Oslo belvárosában, illetve késóbb Utoya szigetén lövöldözött (ICCT 2013).

A norvég kormány rendelkezett kríziskommunikációs tervvel és stratégiával, melynek köszönhetôen a kríziskommunikációs csapat a robbantás után másfél órával fel is állt, ugyan a nyári szabadságok miatt hiányos létszámmal. A tervekhez való hozzáférést a Kríziskommunikációs Titkárság irodai épületének evakuálása és a belső kommunikációs hálózat zárolása gátolta. Az ellenintézkedések elmaradása miatt viszont a média kontroll nélkül tudósíthatott a történésekról. Az Utoya szigetén történtekról a Titkárság is a médiából értesült. Ugyan a kormányzati és rendvédelmi szervek között a sajtótájékoztatókra vonatkozó fő kommunikációs pontok meghatározásra és kommunikálásra kerültek, az információk és a feladatok tervszerú koordinálása elmaradt (FALKHEIMER 2014).

Az esetek mind a katasztrófára való felkészültségben, mind a stratégiai válaszadás szempontjából különböznek, azonban kijelenthetô, hogy a menedzsment- és marketingszemléletú gondolkodás és cselekvés mindkét esetnél bizonyított.

A kutatás eredményeként megállapítható, hogy a kríziskommunikációs folyamatmodell alappillérének számító kríziskommunikációs terv megléte önmagában nem jelenti a válságkezelés sikerét, hiszen a gyakorlati megvalósítás során az eset speciális adottságaihoz kell igazítani a tervet és a cselekvéssort. Az esetek elemzését követően kimondható, hogy a kríziskommunikációs terv nem szükséges feltétele a sikeres válságkezelésnek, sőt nem esetspecifikus gyakorlati megvalósítása a szerzók véleménye szerint további nehézségeket idézhet elő. A turisztikai szervezeteknek, döntéshozóknak válság esetére ezért egy olyan általános terv készítése javasolt, mely megadja a válságkezelés keretét, de nem szab gátat a kreativitásnak. A hatékonyság eléréséhez a különböző katasztrófa szcenáriók felvázolása mellett a folyamatos készenlét biztosítása és a szcenáriók meghatározott időközönkénti gyakorlása is javasolt. Az esetek további tanulságaként levonható, hogy kulcsfontosságú a gördülékeny kommunikáció és a szektor szereplőinek összehangolt kooperációja, mely a válság kezelésének időtartamára is jelentős hatást gyakorol.

\section{5. Összefoglalás}

A tanulmány a turizmusbiztonság szemszögéból ismerteti a szakirodalom releváns elméleti megközelítéseit és modelljeit, melyek hozzájárulnak a turizmusbiztonság fenntartásához vagy meg- 
teremtéséhez. A katasztrófák - akár természeti eredetúek, akár emberi beavatkozás eredményezi őket (például terrortámadások) - minden felkészülés ellenére váratlanul érik a turisztikai desztinációkat, és fenyegetik a turizmusbiztonságot.

A tanulmány során bemutatott két eset - a szájés körömfájás járvány, valamint a bozóttúz elterjedése - a gyakorlatban is szemlélteti a turisták (és helyi lakosok) biztonságát fenyegetô, illetve a potenciális utazási döntéseiket befolyásoló kockázati tényezôket, úgy mint: egészségügyi kockázat (vírusfertőzés), pszichológiai kockázat (pusztítás mértéke, társadalmi felelősségérzet), klíma (bozóttúz megjelenése). A turisták biztonságán túl a desztinációk élővilágát és infrastruktúráját ért pusztítások, illetve a turistaforgalom visszaesése olyan negatív következményei a katasztrófáknak, melyek helyreállítása rengeteg terhet (pénzügyi és idő ráfordítás) ró a desztinációkra.

A krízist és negatív hatásait a turisztikai döntéshozók, turisztikai szervezetek kríziskommunikációs modellek alkalmazásával és tervek elókészítésével tudják mérsékelni. FAULKNER (2001) és az ausztrál Fenntartható Turizmus Kooperatív Kutatási Központ (STCRC 2008) is azt állítja, hogy egy-egy súlyos katasztrófahelyzet olyan kitörési pontként szolgálhat a desztinációknak, mely innovatív megoldásokat, újrapozicionálási stratégiákat, új partnerkapcsolatokat és együttmúködéseket vonhat maga után.

\section{Felhasznált irodalom}

ARMSTRONG, E. K. - RITCHIE, B. W. (2008): The Heart Recovery Marketing Campaign: Destination Recovery After a Major Bushfire in Australia's National Capital. Journal of Travel $\mathcal{E}$ Tourism Marketing. 23(2-4). pp. 175-189.

BAUER A. - BERÁCS J. - KENESEI ZS. (2007): Marketing alapismeretek. Aula Kiadó, Budapest.

BBC (2002): The Foot-and-mouth: The key stats. http://news.bbc.co.uk/2/hi/uk_news/1334466. stm, Letöltve: 2018. március.1.

DÁVID L. - MOLNÁR F. - BUJDOSÓ Z. DERESKEY A. (2007): Biztonság, terrorizmus, turizmus. Gazdálkodás. 51(20). Különkiadás. pp. $160-166$

DÁVID L. - MOLNÁR F. (2007): Biztonság, terrorizmus és turizmus: nemzetközi és hazai relációk. Társadalom \& Politika. 3(1). pp. 33-56.

EISENHARDT, K. M. (1989): Building Theories from Case Study Research. The Academy of Management Review. 14(4). pp. 532-550.

ERNSZT, I. (2016): „Sullen Shadows Under the Blue Sky" - Some Remarks about the Dark Side of Tourism and the International Legal
Protection. In: Németh K. (szerk): I. Turizmus és Biztonság Nemzetközi Tudományos Konferencia. Pannon Egyetem Nagykanizsai Kampusz. Konferenciakötet. pp. 98-106.

FALKHEIMER, J. (2014):"Crisis communication and terrorism: the Norway attacks on 22 July 2011". Corporate Communications: An International Journal. 19(1). pp. 52-63.

FALL, L. T. - MASSEY, J. E. (2005): The Significance of Crisis Communication in the Aftermath of 9/11: A National Investigation of How Tourism Managers Have Re-Tooled Their Promotional Campaigns. Journal of Travel $\mathcal{E}$ Tourism Marketing. 19(2-3). pp. 77-90.

FAULKNER, B. (2001): Towards a framework for tourism disaster management. Tourism Management. 22(2). pp. 135-147.

GÁTI M. - KOLOS K. (2012): Az elektronikus kereskedelem alkalmazása a hazai vállalatok körében - a piacorientáció és a marketingkörnyezet szerepe. Vezetéstudomány. 43. Különszám. pp. 91-97.

HENDERSON, J. C. (2003): Communicating in a crisis: flight SQ 006. Tourism Management. 24(3). pp. 279-287.

ICCT (International Centre of Counter-Terrorism) (2013): The Anders Behring Breivik Trial:Performing Justice, Defending Democracy. https://www.icct. nl/download/file/ICCT-De-Graaf-et-al-TheAnders-Behring-Breivik-Trial-August-2013.pdf, Letöltve: 2018. március 5.

KARL, M. - SCHMUDE, J. (2017): Understanding the role of risk (perception) in destination choice: A literature review and synthesis. Tourism Review. 65(2). pp. 138-155.

KOTLER, P. - BOWEN, J. T. - MAKENS, J. C. (2010): Marketing for Hospitality and Tourism. International Edition. $5^{\text {th }}$ ed. Pearson Prentice Hall, USA.

LEPP, A. - GIBSON, H. (2007): Sensation seeking and tourism: Tourist role, perception of risk and destination choice. Tourism Management. 29(4). pp. 740-750.

MALOTA E. - MITEV A. (2013): Kultúrák találkozása. Nemzetközi kommunikáció, kultúrsokk, sztereotípiák. Alinea Kiadó, Budapest.

MANSFELD, Y. - PIZAM, A. (2006): Tourism Security and Safety: From Theory to Practice. In: Mansfeld, Y. - Pizam, A. (eds): Tourism, Safety and Security. Burlington MA. pp. 139-141.

MICHALKÓ G. (2012): Turizmológia. Akadémiai Kiadó, Budapest.

PÉTER E. - NEMETH K. (2017): Gyorsan sokat? Munkavállalói nézetek változása a pihenési szokásokban. Comitatus: önkormányzati szemle. 27(3). Különszám. pp. 60-63. 
RAFFAY Á. (2017): A marketing szerepe a turizmusban - közös élményteremtés. In: Lőrincz K. - Sulyok J. (szerk): Turizmusmarketing. Akadémiai Kiadó, Budapest. p. 21.

REISINGER, Y. - MAVONDO, F. (2005): Travel Anxiety and Intensions to Travel Internationally: Implications of Travel Risk Perception. Journal of Travel Research. 43(3). pp. 212-225.

RITCHIE, B. W. - DORRELL, H. - MILLER, D. MILLER, G. A. (2004): Crisis Communication and Recovery for the Tourism Industry. Journal of Travel E Tourism Marketing. 15(2-3). pp. 199216.

ROEHL, W. S. - FESENMAIER, D. R. (1992): Risk perceptions and pleasure travel: an exploratory analysis. Journal of Travel Research. 30(4). pp. 1726.

STCRC (2008): Impact of bushfires on tourism and visitation in alpine national parks. http:// citeseerx.ist.psu.edu/viewdoc/download?doi= 10.1.1.563.8548\&rep=rep1\&type=pdf, Letöltve: 2018. március 6.

TÓTH-KASZÁS N. (2017): A marketingkommunikációs mix - Az integrált marketingkommunikáció. In: Lőrincz K. - Sulyok J. (szerk): Turizmusmarketing. Akadémiai Kiadó, Budapest. pp. 233-254.

UNWTO (World Tourism Organisation) (2016): UNWTO Tourism Highlights 2016
Edition. https://www.e-unwto.org/doi/ pdf/10.18111/9789284418145, Letöltve: 2018. február 10.

UNWTO (World Tourism Organisation) (2017): UNWTO Tourism Highlights 2017 Edition. https://www.e-unwto.org/doi/ pdf/10.18111/9789284419029, Letöltve: 2018. február 15.

UNWTO (World Tourism Organisation) (2018): 2017 International Tourism Results: the highest in seven years. http://media.unwto.org/pressrelease/2018-01-15/2017-international-tourismresults-highest-seven-years, Letöltve: 2018. február 25.

WTTC (World Travel \& Tourism Council) (2017): Travel \& Tourism, Economic Impact 2017. https://www.wttc.org/-/media/ files/reports/economic-impact-research/ regions-2017/world2017.pdf, Letöltve: 2018. február 24

YANG, E. C. L. - NAIR, V. (2014): Tourism at risk: A Review of Risk and Perceived Risk in Tourism. Asia-Pacific Journal of Innovation in Hospitality and Tourism. 3(2). pp. 239-259.

ZSARNOCZKY, M. (2017): The Future of Sustainable Rural Tourism Development Impact of Climate Change. Annals of the Polish association of agricultural and agribusiness economists. 19(3). pp. 337-344. 